\title{
Genetic Gestational Surrogacy: Hope for Muslims
}

\author{
Shamima Parvin Lasker ${ }^{1}$, Marcello Ghilardi²
}

1. PhD (USA), MPH (USA), EMMB (Europe), MPhil (BD), MSc (BD);

Professor \& Head of Anatomy, MH Samorita Medical College, Dhaka, Bangladesh.

Visiting Professor of Clinical Anatomy \& Bioethics, American University of Sovereign Nation, USA.

Founding Chairman \& Sectary General, Bangladesh Bioethics Society.

Treasurer, World Association of Medical Editors (WAME)

Chairperson, Ethics \& Publication, Asian Pacific Association of Medical Editors (APAME)

Email: splasker04@yahoo.com

2. PhD, Assistant Professor, University of Padova, Italy.

Email: ghilardimarcello@gmail.com

\begin{abstract}
More than half a million couples may be suffering from infertility in the world. When in vitro fertilization is unsuccessful, surrogacy may be a substitute choice for many couples. Literature shows that ten million Muslims are infertile worldwide. According to Islamic theology the concept of surrogacy is null and void as formation of blastocyst constitutes from sperm that is transferred to the uterus of a woman who is not married to him. In Islam, marriage is the only legal procedure to procreation for preservation of lineage, inheritance, prevention of adultery and prevention of possibility of incest among the half-siblings. Genetic gestational surrogacy (sperm of husband and ovum of wife is fertilized by IVF procedure and transfer the embryos to the surrogate mother) may be free from social, legal and moral complications. Some Islamic countries have reluctant law in favour of surrogacy, as for example Iran, Lebanon and sporadic parts of the Muslim world. This article has attempted to find out a valid notion for accepting genetic gestational surrogacy in major part of the Muslim world that may reduce the peril of women who can not give a birth baby.
\end{abstract}

\section{Key Words: surrogacy, Islam, bioethics}

1. Introduction: Assisted reproductive technology (ART) has been fascinated by the public after the news of "Louise Brown, the first test tube baby", in 1978'. Infertile couple are inclined to ART including donation of gamete (sperm / egg) and surrogacy in an immense expectation ${ }^{2}$. However, this new technology for infertility generates debate worldwide. The main ethical, social and legal problem are raised from natural, partial and unrelated gestational surrogacy. Fundamentally, there is no the social, legal and moral complication in genetic gestational surrogacy. It is the last alternative for infertility treatment who wants their own genetic baby ${ }^{3}$. Nonetheless, the widespread uses of such technologies are prohibited by Muslim.
Sunni and Shiite are the two main schools of thought in Muslim 2. Sunni scholars disallow surrogate motherhood, since surrogate mother will carry the baby formed by other man's sperm to whom she is not married 2,4. They consider the union of ova/sperm other than wife/ husband is as adultery. According to Islamic jurisprudence, legal marriage is the only precept for the procreation and a child is illegitimate if marriage is null and void 5 . Therefore third party reproduction is challenging in Islam.

On the other hand, Shiite scholars do permit surrogate motherhood only for legal couples as the treatment of infertility. Therefore, surrogacy is being practiced by Shiite population in Iran, Lebanon and few other part of the Muslim world 2,6,7. According to Shiite theology, self of embryo is seen totally different from the sperm. They do not consider implantation of embryo 
into the surrogate mother's uterus as similar as "sperm of man to whom she is not married" 8 . Basically, they consider surrogate procedure as transferring of foetus from one uterus to another and they do not see any sin in this practice ${ }^{9}$.

It is obvious that surrogacy was not mentioned in the Qur'an and was not practised at the time of Mohammad. But Qur'an asserted the significance of family formation, marriage, and procreation ${ }^{9}$. Some Sunni scholars feel that the use of surrogate motherhood is permissible in Sunni. Because according to Islamic law, preservation of the human species is one of the primary objectives of Islam 2. Moreover, Hadit says Allah provided a cure to every suffering as $\mathrm{He}$ promises 10, 11. With the advancement of science and technology this promise is now become real. Although infertility cannot be totally eradicated, but researchers can able to help childless couples to have a child of them.

However, there is a gap between the Islamic scholars regarding the notion of surrogacy. This article has discussed about the Islamic philosophy and theology on surrogacy and has evaluated the main problems, the presuppositions and the conviction involved in the controversy about the genetic gestational surrogacy in Islamic culture under the research question "can genetic gestational surrogacy be ethically possible to accept in major part of Muslim world?"

Research Methodology: Literature review is the basis of this retrospective normative research. Articles on surrogacy were thoroughly searched from the year of 1990. Google scholar, Pubmed, Web of science and Embase were the possible search engine. Key words were Islam, surrogacy, ethics and bioethics respectively. This article was written as the requirements for the degree of Erasmus Mundus Master of Bioethics at KU Leuven, Belgium in 2011.

Social Condition of Infertile People: Infertility may cause intolerable situation for many couples by their family, particularly, who have come from conservative and traditional Islamic family ${ }^{13}$. Procreation potentiality dignifies the Muslim women, increases their social status, their dignity and self-esteem. It is their social commitments to the family to give birth and rear up children in addition to biological and social functions. Moreover, Islamic family law envisage wife's infertility is the major ground for divorce and vice versa. Therefore, childless women are always in psychological pressure that their marriages will breakup. However, marriage is usually not end up in the ground of male infertility ${ }^{4}$.

Although in about $50 \%$ of cases, male is the cause of infertility, but social burdens are carried disproportionately by the female ${ }^{14}$. Interestingly, some infertile men marry again as a solution of infertility. However, this marriage brings more suffering for the first wife like a two edge saw ${ }^{13}$ due to negligence and domestic violence ${ }^{15}$ which ultimately violate the basic human rights of first wife. In some society childless women are excluded from family functions such as birthdays, marriage ceremony and other event of children ${ }^{16}$ In some countries, infertile couples are regarded as a socioeconomic burden due to loss of continuity, rights to property and inheritance, and discontinuity of family name ${ }^{15}$. In some culture, childless couples suffer from insecurity. In this culture, children supports economically and socially to family and provide reversible duty to parents when they become old" ${ }^{17}$. In egalitarian societies, people want children as part of their life plan and they suffer when they cannot fulfil their wish"18. Therefore, importance of infertility treatments particular in the Muslim World is needed.

Definition and Classification of Surrogacy: Dictionary meaning of surrogacy is alternate, substitute or proxy. Surrogate mother is she who carries the embryo on her womb to term and gives birth a baby on behalf of another couple. If surrogate mother is impregnated with the semen of other man by national process of body contact is known as traditional surrogacy or straight surrogacy. If an ovum or a sperm is collected from a third person and then fertilized in the laboratory and resulting embryo is transferred to the couples' wife is known as partial surrogacy. When both the ovum and sperm are fertilized in vitro and transfer to surrogate mother, is known as gestational 
surrogacy. Gestational surrogacy are two types. When both the ovum and sperm are donated and fertilized in vitro and the resulting embryos are embedded to the uterus of surrogate mother, is known as full surrogacy or unrelated gestational surrogacy. If sperm and ovum are taken from intended couple and fertilization in vitro and the resulting embryo is transferred to the surrogate mother is known as genetic gestational surrogacy ${ }^{3}$. In gestational surrogacy, surrogate mother is not genetically related to the child. She has no responsibilities to rare up child after delivery.

Islamic Jurisprudence on Surrogacy: Islamic jurisprudence (Sharia Law) regulates the daily living of the followers and shapes the people life to safeguard the peace, contentment and welfare in the society 19 . Sharia Law is based on four source. The first and the most vital source is the Qur'an. The second basis is Hadit or Sunna, the act was done or approved by Prophet Muhammad (died $632 \mathrm{AD}$ ). The third foundation is the agreement of Doctors of Law (Mufti, Fuqaha) and Islamic scholars (Ulama, Aimma) is called ljma, and the fourth is analogy (qiyas), act as similar as Arab tradition during Mohammad period ${ }^{8}$. Muslims access the Hadit if there is no guidance in Qur'an. If the hadits have no guidelines for a particular enquiries for clarification, Muslim seek guidance from Doctors of Law and Islamic scholars in the form of consensus. In certain situations, Islamic scholars clarify the rules analogy to situation of Mohammad period. If none of three provides an answer, Muslim scholars must depend on individual intellect (ljtihad) to make a judgment in view of necessity, public interest and the principle of "no harm" 20,21,22 .

Despite, the Qur'an categorically presents all the guidelines and directives of life, but it does not explicitly focus on every possible situation a Muslim may face now a day. As for example ART. Islamic scholars address the ART and provide verdicts. Usually verdict comes from Al-Azhar University in Egypt, the oldest and most important religious university for Muslim and the International Islamic Fiqh Academy in Jeddah, Saudi Arabia ${ }^{23}$. In 1980, Grand Shaykh of Al-Azhar University, issued the first bioethical decrees on ART. It permits treatments of all kind of ART but third-party reproduction in any form is rejected including surrogacy ${ }^{4}$.

Ideological Difference between Sunni and Shiite: Sunni are the followers of Mohammad and Shiite are the follower of Ali. Imam Ali was the cousin of Mohammad and fourth successor I ruler of Islam after Mohammad died. Majority $(90 \%)$ Muslims are Sunni in the world ${ }^{8}$. Sunni examines all the contemporary critical social, legal, ethical and medical issues mainly in the light of Sharia law, though they have tradition to use ijtihad. On the other hand, Shiite deals the newly emerging issues by use of individual intellect (ijtihad) in addition Sharia ${ }^{24}$.

ljtihad has led to a great difference between Shiite and Sunni ${ }^{25}$. Shiite religious authorities exercise ijtihad a grater extends in question of moral goodness and badness on the basis of individual intellectual reasoning. Consequently, contemporary emerging ethical issues are discussed and categorized in the light of both scripture and intellect and provide verdict (Fatwa). Highest-ranked religious authorities (Grand Ayatollahs) can only issue a fatwa ${ }^{13}$. In 1999, Ayatollah Ali Hussein Khamanei, the Supreme leader of Iran, issued a religious verdict on reproductive technology that permitting the donor technologies including surrogacy. Prevention of breakage of marriage and psychological disputes have prioritized in this verdict ${ }^{6}$. Though Shiite, is powered by authoritarian systems in some cases, however, all bioethical verdicts do not basically vary from the Sunni positions ${ }^{26}$.

Islamic Philosophy on Surrogacy: Two years after the birth of $1^{\text {st }}$ test tube baby, Islamic scholars issued bioethical decrees on medically assisted reproduction, permitting treatment for all type of ART, but prohibited third-party reproductive technology, including surrogacy. Philosophical interpretations for prohibition of the third-party reproductive assistance are as follow:

Adultery: According to Islam, marriage is an agreement of sex and procreation between couples. Third person is not allowed into the connubial functions ${ }^{5}$. Qur'an describes 
"Those who guard their private parts except from their spouses... but whoever seeks to go beyond that, these are they that exceed the limits" (Quran Sura Al-Mu'minun 23: 5 \& 7) ${ }^{27}$.

"Reproduction outside of marriage is considered as adultery (zina)" 27 . The moral implication of the embryo transfer other than wife is tantamount to adultery. Sperm/ eggs donation is prohibited in Islam as it annihilates the lineage ${ }^{5}$. "Islam noted adultery as a punishable crime in order to preserve the lineage " 5 .

Lineage: The legal importance of family, lineage and blood relations is markedly noticeable in Islam ${ }^{28}$. The Qur'an mentions

"It is $\mathrm{He}$ (Allah) who created mankind from water, then has $\mathrm{He}$ established the relationship of lineage and marriage for your Lord has power over all things" (Qur'an Sura Al-Furqan 25: 54) ${ }^{29}$.

Destruction of genealogical lineage (especially patrilineal) may have two way devastating interference for kinship and inheritance 5 . Third-party donation is difficult in Islam as it destroys a child's lineage, which may have psychologically suffering for the child in one hand. On the other hand, father may be reluctant to do his duties and responsibilities to the child if he knows that the child does not genetically belong to him specially during social and economical hardship. In addition, child may face domestic violence. Moreover, in Islam, child has right to inherit the property of his or her genetic parents only ${ }^{30}$. Therefore children conceived in third party arrangement may have devastating consequences.

Some may argue that the third party donation should be seen as similar as child adoption thereby, a child can use surname from adoptive parent ${ }^{31}$. However, the Quraan encourages kind upbringing of an orphan but explicitly prohibits adoption ${ }^{32}$.

"If a child is not the person's real child, it cannot become so merely by virtue of a declaration. Claiming an adopted child as one's own deprives the real heirs of certain rights. He has not made your wives whom you declare unlawful your mothers. And he has not made your adopted sons your [true] sons. That is [merely] your saying by your mouths, but Allah says the truth, and He guides to the [right] way. Call them by [the names of] their fathers; it is more just in the sight of Allah. But if you do not know their fathers - then they are [still] your brothers in religion and those entrusted to you. And there is no blame upon you for that in which you have erred but [only for] what your hearts intended. And ever is Allah Forgiving and Merciful (Qura'n Sura Al Ahzab 33:4-5) ${ }^{32}$.

Islam implies purity of lineage and significance of information of one's personal familial lineage 33. Hiding from child true genetic lineage and heredity, Islam considers it as deceit ${ }^{34,35}$. Islam gives right to know one's parentage fully. Lack of information of one's lineage may cause one to marry a half-brother, half-sister ${ }^{4}$.

Incest among the half-siblings: Qura'n explicitely defines certain relationships between which there cannot be any marriage at all ${ }^{36}$.

"Forbidden unto you are your mothers, and your daughters, and your sisters, and your father's sisters, and your mother's sisters, and your brother's daughters and your sister's daughters, and your foster mothers, and your foster sisters, and your mothers-in-law, and your step daughters who are under your protection (born) of your women unto whom you have gone in but if you have not gone in unto them, then it is no sin for you (to marry their daughters) and the wives of your sons who (spring) from your own loins. And (it is forbidden unto you) that you should have two sisters together, except what has already happened (of that nature) in the past. Lo! Allah is ever Forgiving, Merciful."

"Lawful unto you are all beyond those mentioned, so that you seek them with your wealth in honest wedlock, not debauchery. So wed them by permission of their folk, and give unto them their portions in kindness, they being honest, not debauched nor of loose conduct." (Qur'an Surah An-Nisa 4: 23) ${ }^{36}$.

Anonymous donors may cause potential "incest among the half-siblings". Third party reproductive technology may harm not only to the individuals involved, but in a long run to the society as a whole ${ }^{37}$.

Discussion: Islamic bioethics, theology, philosophy or jurisprudence is scriptural; therefore, amendment is critical along with 
paradigm shift. According to Islam, the third party donation of procreation is prohibited. Adultery, possibility of "incest among the halfsiblings" from unknown donors and genealogical lineage are the concern in partial and genetically unrelated surrogacy. Therefore, third party donation and unrelated surrogacy are virtuously wrong and banned from the standpoint of Islamic ethics. Genetic gestation surrogacy may have still room to discuss.

In genetic gestational surrogacy, breakdown of lineage is impossible as the biological parents are already known. Actually surrogate mother is not engaged in any act of adultery in this procedure, as there is no involvement sexual body interaction of adulterous relations, hence, the punishment of adultery is not applicable. By virtue, introducing an extramarital third party engagement may threaten the marital bond of husband and wife ${ }^{37}$.

Only question can arise from genetic gestational surrogacy is "who is the real mother, the genetic mother or the birth mother?" Qur'an defines motherhood as

Their mothers are only those who conceived them and gave birth to them (waladna hum) (Al Quran Surah al-Mujadalah 58: 2) ${ }^{38}$.

The Arabic word "walada hum" means the whole procedure of pregnancy from fertilization to perturation. It is not just act of carrying (haml) or delivery (wad') ${ }^{37-40}$. Thus, Qur'an denies unconditionally any rights to genetic mother in surrogate arrangement.

Actually, the Islamic bioethics is based on four doctrines of "necessity, public benefit, local custom, and justice"21,26,41.

But if one is compelled by necessity, neither craving nor transgressing-there is on him no sin, for indeed God is Clement, Merciful. (Quran Sura AI Bakara 2:v. 173) ${ }^{42}$.

In context of absolute necessity, Islam sometimes allows forbidden actions suspending the sharia law if there are no religiously legitimate alternatives exist. As for example the insulin and heart valves. Insulin is manufactured from pork and a heart valve is made from pig. Qur'an repeatedly prohibits consumption of pork for Muslim. However, Islamic scholars allow medical treatment with pork insulin and pig heart valves on the principle of necessity and public benefit ${ }^{35}$. Further, Maturation is prohibited by Qur'an ${ }^{27}$.

"The successful believers] who abstain from sex, except with those joined to them in the marriage bond, or (the captives) whom their right hands possess, for (in their case) they are free from blame, but those whose desires exceed those limits are transgressors ... (Qur'an, Sura al- Muminun 23: 5-7) 27 .

But masturbation is allowed for the collection of sperm for ART with substantial arguments of necessity and public benefit. ${ }^{43}$. Another, the donation or transplantation of sexual organs is Haram (forbidden, sinful) by Qur'an 44,45,46. However, in April 2000, first uterus transplantation has been successfully attempted in Saudi Arabia and the second human uterus is transplanted in Turkey in August 201144,46 . Though the donation or transplantation of sexual organs is prohibited by Qur'an but it is allowed to fulfil the Islamic principle of procreation and maintaining the family lineage. In favour of argument of uterus transplantation, it is explain that the main function of the uterus is holding a developing fetus to maturity, it is not something that relates directly to the carrying of the inherited genes of the infant ${ }^{45}$. In genetic gestational surrogacy, surrogate mother is merely carrying baby in her womb till birth. There is no chance of carrying of the inherited genes of the infant in this case as well.

There are many more example in Islam where prohibited action become permissible violating the primary source (Qur'an) for greater necessity and public benefit. These do not generate any legal and moral problem vis a vis Islamic guidelines.

Moreover, Qur'an repeatedly encouraged marriage, family formation and reproduction.

Wealth and progeny are the allurements of this world (Al Quran, Surah 14:46) ${ }^{47}$. or 
We did send apostles, before thee, and appointed for them wives and children" (Quraan Sura Al-Ra'd $13: 38)^{9}$.

Preservation of the human species as one of the primary objectives (maqasid) in Islam. Therefore, if a married couple enable to give birth a child, their inability should be overridden by treatment. If genetic gestational surrogacy is one method, ban can be adjourned in light of principle of primary objective that is procreation.

However, Qur'an acknowledges significant hardship of infertility. Examples of two childless prophets e.g. Abraham and Zacharyyia has been described in Quran and depected how they longed to Allah and pray sincerely and continuoiusly with faith to have a child of their own, even as they grew old. God answered their prayers and they had had themselves son with knowledge.

And those who pray, Our Lord, grant unto us spouses and offspring who will be the comfort of our eyes (Al Quran Sura Al Furqan 25:74). ${ }^{48}$

Moreover, Prophet Muhammad says,

For every disease, there is a cure except senility (Hadit, Bukhary and Muslaam) ${ }^{10}$.

Prof Abul Fadl Moshin Ebrahim, Emeritus Professor of Religious, Philosophy and Classic, University of Kwa Zulu-Natal, Durban, argued that if the state of infertility is think of a "disease", then it should be allowed to seek tratment to overcome infertility ${ }^{49}$. As the genetic gestational surrogacy has no moral and socio-legal complications, it should be permitted to childless couples whose family continuity is always an impossible.

Still, motherhood has seen problematic in genetic gestational surrogacy. Who is the real mother? According to definition of motherhood in Qur'an, mother is she who carry and gives birth baby. However, in May 2004, Ezyptian sheikh Abdel Rahman Al Adawy, head of the council jurisprudence Research Committee, raise question, who is the mother of the child in case of uterus transplantation? Does mother can donate uterus to her daughter or vis versa
${ }^{8}$ ? Same questions may rise again whether it is allowed where introducing of "sperm of a man into the uterus of a woman to whom he is not married". Political motivation weighing the necessity and public benefit overcomes the above mention question in case of uterus transplantation.

However, the notion of milk mother or wet nurse (hiring a breast feeding woman to feed a child whose mother enable to breast feeding to child or died during delivery) is an acceptable practice in Arab tradition even practised in prophet Mohammad himself situation 37.39,40. This can be used as an analogy model for the genetic gestational surrogacy. Surrogate mother is merely carrying baby in her womb in hardship of other sister who is unable to give birth baby due to cancer or disease. Genetic mother will provide tissues (ova and sperm), whereas the gestational mother will be responsible to provide nutritional input to build up in her womb like the milk mother. It protects human rights to life, so this practice will not bring any psychological and social harm to achieve final good.

Basically, genetic gestational surrogacy has no social, ethical, legal and theological impediment. A political approach of motherhood is only problematic in this method. As both the biological and genetic mother does not commonly satisfied the definition of motherhood, so justice can be employed to genetic mother as the lineage is already proofed. Quran says Islam is not religion of hardship (Usr) but a religion of ease (Yusr) ${ }^{49}$. Furthermore, "the Sharia is not a rigid law rather it is flexible enough" to accommodate different honest opinions that have direct benefit of humanity ${ }^{22}$. Only the political motivation is needed in case of genetic gestational surrogacy to over ruled the prohibition.

Conclusion: Available literature shows that the artificial reproductive technology is allowed in Islam but it disallow all type of third party assistance reproduction as it encompasses adultery, destruction of lineage, inheritance problem and incest among the half-siblings. In these four grounds natural, partial and 
genetically unrelated full surrogacy actions have brought out debate, disagreement, and controversy. There is no questions of above mentioned four problems in genetic gestation surrogacy except question of motherhood. Justice can be employed giving the motherhood to genetic mother for preservation of lineage. Only the political motivation is needed in the case of genetic gestational surrogacy.

Limitation: Many books and articles have been published in Arabic, Farsi and other language locally that are not included in this brief manuscript. Articles written also remain outside of discussion due to inability of access foreign language. Only English and translated literature has been considered for this article.

Competing Interests: The authors declare no competing interests.

Author Contribution: $1^{\text {st }}$ author conceive the idea, done literature review and wrote the manuscript. $2^{\text {nd }}$ author guide to write the manuscript and check the manuscript meticulously.

\section{References:}

1. Norhayati HA. Assisted Reproduction Islamic views on the science of procreation. Eubios $\mathrm{J}$ of Asian and Intern Bioethics 2003; 13 :59-61.

2. Serour GI. Islamic perspective of ethical issues in ART. Middle East Fert Soc $J$ 2005;10(3): 185-190.

3. Brinsden RP. Gestational surrogacy. Human Reproduction Update 2003; 9(5):483-491.

4. Inhorn MC. Making muslim babies: IVF and gamete donation in sunni versus shi'a islam. Culture, Medicine and Psychiatry 2006; 30: 427-450

5. Inhorn MC, Patrizio P and Serour GI. Thirdparty reproductive assistance around the Mediterranean: comparing Sunni Egypt, Catholic Italy and multisectarian Lebanon Reproductive BioMedicine Online 2010; 21, 848- 853.

6. Abbasi-Shavazi MJ, Inhorn MC, RazeghiNasrabad HB and Toloo G. The Iranian ART revolution: infertility, assisted reproductive technology, and third-party donation in the Islamic Republic of Iran. J. Middle East Wom. Stud. 2008; 4:1-28.

7. Larijani B and Zahedi F. Contemporary medical ethics: an overview from Iran. Dev World Bioeth 2008; 8:192-196.
8. Atighetchi $\mathrm{D}$.Islamic bioethics problem and perspective, Netherlands, Springer, 2007 page 180.

9. Al Qur'an, Sura Al-Ra'd 13:v. 38.

10. Hadith Bukhari. Khan Muhammad $M$ (Trans). 1995.. Al-Lu'lu' wal Marjan. A Collection of Agreed Upon Hadith From alBukhari and Muslim. Dar-us-Salam Publications: Riyadh.

11. Hadit Muslim. Khan, Muhammad $M$ (Trans). 1995.. Al-Lu'lu' wal Marjan. A Collection of Agreed Upon Hadith From alBukhari and Muslim. Dar-us-Salam Publications. Riyadh.

12. Hadit Abou Dawood. Khan Muhammad M (Trans). 1995.. Al-Lu'lu' wal Marjan. A Collection of Agreed Upon Hadith From alBukhari and Muslim. Dar-us-Salam Publications:Riyadh.

13. Aramesh K. Iran's experience with surrogate motherhood: an Islamic view and ethical concerns. J. Med. Ethics 2009; 35; 320-322.

14. Ayesha SC. Unlikely Motherhood in the Qur'ann: Oncofertility as Devotion. Cancer Treat Res 2010; 156: 287-94.

15. Ombelet WIC, Silke D, Serour GI and Devroey P. Infertility and the provision of infertility medical services in developing countries. Human Reproduction Update, 2008;14(6): 605-621.

16. Macro ORC and lqbal HS. Demographic and Health Surveys (DHS) Comparative reports No. 9. Infecundity, infertility, and childlessness in developing countries. World Health Organization 2004. however (access in 2010 November 29).

17. Lasker SP. Infertility treatment in developing country. Bangladesh $J$ Bioethics 2011; I (2):3.

18. Abduljabbar SA and Amin R. Assisted reproductive technology in Saudi Arabia. Saudi Med J 2009; 30(4):461-464.

19. Maududi AA: The Islamic Concept of Life. In: http://www.islam101.com/sociology/concep tLife.htm. (Accessed on April . 24, 2012.)

20. Syed IB. ljtihad. In: http://www.irfi.org/articles/articles_1_50/ijtih ad.htm. (Accessed on April 24, 2010).

21. Atighetchi D. Problems of Islamic Bioethics and Biolaw. Derecho y Religion 2007; 2:221-229

22. Ahmad NH. Assisted reproduction- Islamic view on science and procration. Eubios $J$ Asian Intern Bioethic 2003; 13: 56-61.

23. Ruaim A. Muaygil. Re-examining the prohibition of gestational surrogacy in Sunni Islam. Developing world bioethics 2016, John Wiley \& Sons Ltd pp 1-9.

24. Velaee EG. The rules of Islamic jurisprudence. Dar-ol-fekr, 2008:10-15.

25. Zoloth $L$ and Henning $A A$. Bioethics and oncofertility: Arguments and Insights from Religious Traditions. Cancer Treat Res 2010; 156: 261-278. 
26. Daar SA and Khitamy ABA. Bioethics for clinicians: 21. Islamic bioethics. CMAJ 2001;164(1):60-63.

27. Al Quran Sura Al Mu'minun 23, v. 5, 6, 7 .

28. Fasouliotis SJ and Schenker JG. Social aspect of assisted reproduction. Hum. reprod.update1999;5(1):26-39.

29. Al Qur'an, Sura Al-Furqan 25:v. 54.

30. Fadel HE. The Islamic Viewpoint on new assisted reproductive technologies. Fordham Urban Law J 2002; 30(1):147157.

31. Clarke M. Shiite Perspectives on Kinship and New Reproductive Technologies. ISIM Review 2006; 17: 26-27.

32. Al Qur'an, Sura Al Ahzab 33: v. 4-5.

33. Serour GI. Ethical Considerations of assisted reproductive technologies: a Middle Eastern Perspective. Opinion. Middle East Fertile Soc J 2000; 5:1:13-18.

34. Serour GI. Bioethics in Infertility Management in the Muslim World http://www.islamic-world.net/sister/h12.htm (access in 2011 December 2).

35. Gatrad A R and Sheikh A. Medical ethics and Islam: principles and practice. Arch Dis Child 2001; 84:72-75.

36. Al Quran, Surah An-Nisa 4: v. 23

37. Kholwadia SMA. The Islamic Ruling on Surrogate Motherhood, http://www.ilmgate.org/the-islamic-rulingon-surrogate-motherhood/ (accessd on $27^{\text {th }}$ Feb 2012).

38. Al Quran Surah al-Mujadalah 58: v. 2.

39. Kabir M and az-Zubair B. Who is a parent? Parenthood in Islamic ethics. J Med Ethics 2007; 33:605-609.

40. Zuhur, Sherifa 1992 Of Milk-Mothers and Sacred Bonds: Islam, Patriarchy, and New Reproductive Technologies. Creighton Law Review 25:1725-1738.

41. Weber AS. Bioethical Reasoning in Islam. International Journal of Arts and Sciences 2010; 3(15): 607-617.

42. Al Quran. Sura Al Bakara 2:v. 173.

43. Sharmin I, Rusli BN, Rani A and Hanapi BMN. Ethics of Artificial Insemination: An Islamic Prospect. JIMA 2007; 39: 29-32.

44. Amel Alghrani. Regulating novel methods of reproduction: Womb transplantation and Islamic Bioethics. QScience Proceedings: Vol. 2012 . http://www.qscience.com/doi/abs/10.5339/ qproc.2012.bioethics.5.7 (Access January 2013)

45. Morgan Clark. Fertility, Reproduction and Sextuality. In vol 16, Islam and new kinship, Reproductive technology and Sharia in Lebanon, Berghan Books, 2009 Page 107 oxford.

46. Al-Qardawi, Yusuf (1999). The Lawful and the Prohibited in Islam. American Trust Publications. p. 82.

47. Al Quran, Sura Al-Shura 14:v. 49-50.

48. Al Qur'an Sura Al Furqan 25:v.74.
49. Ebrahim AFM. Biomedical issues: Islamic perspective. Kuala Lumpur: A.S. Noordeen; 1993. 